\title{
A Comparism of Sorghum Yield between Local Varieties in Turare, Katsina State and Sorghum Hybrids from IAR Zaria, Kaduna State
}

\author{
Hassana Maryam $\mathrm{Ati}^{1}$ and Mudashiru Akinyemi ${ }^{2}$ \\ 1. Department of Crop Production and Protection, Faculty of Agriculture \& Agricultural Technology, Federal University, \\ Dutsin-Ma, Katsina state 821101, Nigeria \\ 2. Department of Agricultural Economics \& Extension, Faculty of Agriculture \& Agricultural Technology, Federal University, \\ Dutsin-Ma, Katsina state 821101, Nigeria
}

\begin{abstract}
Nine sorghum varieties comprises of five hybrids from IAR, Zaria and four local varieties from Turare local community were evaluated at Turare village in Dutsin-Ma, Katsina state to compare their performance with the aim of selecting the sorghum with the best performance in yield for multiplication and distribution to the local farmers. The experiment field was laid using randomized complete block design (RCBD) with three replications. Random table number was used to allocate sorghum varieties to plots. Among the nine varieties, Samsorg 45 was the best performed variety in agronomic characteristics and yield followed by Samsorg 46 and then Samsorg 40. These three varieties were selected among the nine varieties. The study concludes that Samsorg 40, 45 and 46 have a better attributes of early maturity, yield and higher nutritive value. This will relatively translated to higher income for the farmers. It is therefore recommended that farmers should be sensitized and educated on their planting.
\end{abstract}

Key words: Varieties, yield, agronomic characteristics, performance and grain.

\section{Introduction}

Sorghum is classified under the family of Poaceae, tribe Andopogoneae, subtribe Sorghinae, genus Sorghum. Sorghum (Sorghum bicolor L. Moench) is the fifth most important cereal crop in the world after wheat (Triticum aestivum L.), rice (Oryza sativa L.), maize (Zea mays L.) and barley (Hordeum vulgare L.). Sorghum and millets are important crops for food security in semi-arid and arid regions due to their high nutritional quality, tolerance to stresses (abiotic and biotic) and their performance in marginal lands with relatively low fertility. Sorghum is grown in a wide range of climates from the equator to over $50^{\circ} \mathrm{N}$ and $40^{\circ} \mathrm{S}$ and at altitudes from sea level up to $1,000 \mathrm{~m}$. Sorghum is well adapted to hot, semi-arid tropical

Corresponding author: Hassana Maryam Ati, Ph.D., research fields: plant breeding and biotechnology. environments and is relatively more drought- and (high) temperature-tolerant when compared to other cereal crops (rice, wheat or maize). Although sorghum has a maximum yield potential similar to that of other cereal crops, its yields are generally much lower. This is mainly due to its exposure to extreme heat (high temperature) and drought, as the crop is often grown during the hottest seasons of the year, in areas with limited rainfall and in marginal or poor soils [1].

Sorghum has been, for centuries, one of the most important staple foods for millions of poor rural people in the semi-arid tropics of Asia and Africa. For some impoverished regions of the world, sorghum remains a principal source of energy, protein, vitamins and minerals. Sorghum grows in harsh environments where other crops do not grow well, just like other staple foods, such as cassava, that are common in impoverished regions of the world. It is usually grown 
without application of any fertilizers or other inputs by a multitude of small-holder farmers in many countries [2]. According to Ref. [3], high temperature $\left(30-36^{\circ} \mathrm{C}\right)$ reduces sorghum seed set and pollen germination though genotypes differed in their tolerance to high temperature stress. Exposure of sorghum during flowering for 10-15 $\mathrm{d}$ high temperature $\left(36-38{ }^{\circ} \mathrm{C}\right)$ reduces pollen germination, failure of fertilization and flower abortion [4-6].

Sorghum is about $70 \%$ starch, so is a good energy source. Its starch consists of $70 \%$ to $80 \%$ amylopectin, a branched-chain polymer of glucose and $20 \%$ to $30 \%$ amylose, a straight-chain polymer. The digestibility of the sorghum starch is relatively poor in its unprocessed form, varying between $33 \%$ and $48 \%$. Processing of the grain by methods such as steaming, pressure cooking, flaking, puffing or micronization of the starch increases the digestibility of sorghum starch. This has been attributed to a release of starch granules from the protein matrix, rendering them more susceptible to enzymatic digestion.

Sorghum is well adapted to growth in hot, arid or semi-arid areas. The many subspecies are divided into four groups - grain sorghums (such as milo), grass sorghums (for pasture and hay), sweet sorghums (formerly called "Guinea corn", used to produce sorghum syrups) and broom corn (for brooms and brushes). The name "sweet sorghum" is used to identify varieties of S. bicolor that are sweet and juicy.

Sorghum is used for food, fodder and the production of alcoholic beverages. It is drought tolerant and heat tolerant and is especially important in arid regions. It is an important food crop in Africa, Central America and South Asia and is the "fifth most important cereal crop grown in the world". Although sorghum is an indigenous crop exceptionally adapted in the region, the yields are generally less than $1.5 \mathrm{t} / \mathrm{ha}$ [7]. Important factors among which that contribute to these low yields includes: low input, poor soil fertility and the non-availability of improved varieties or hybrids with significant yields superiority over farmers land race varieties [7].

Sorghum is an important cereal coming on the 5th position after maize, rice, wheat and barley at world level due to its importance in human nutrition, animal feed, in producing bioethanol and green energy, and due to its good impact on environment. It is cultivated on all the continents, in the tropical, subtropical and temperate areas due to its resistance to drought, production potential, low inputs and production cost. It is an alternative to maize crop being more utilized as substituent in animal diets. The world sorghum production reached 63,811 thousand metric tons in 2014, the main producers being the USA, Mexico, Nigeria, India, Argentina, Ethiopia, Sudan and China [8]. Sudan accounts for $21.4 \%$ of Africa's sorghum production, second to Nigeria, which produces $33.8 \%$ of the total harvest. Ethiopia accounts for $7.3 \%$, Tanzania 3.5\%, Uganda $2 \%$, Rwanda $0.8 \%$ and Kenya $0.6 \%$ [9]. Average productivity estimates show that the mean yield in Africa is about $800 \mathrm{~kg} / \mathrm{ha}, 1,200 \mathrm{~kg} / \mathrm{ha}$ in Asia, 4,000 kg/ha in America and $5,000 \mathrm{~kg} / \mathrm{ha}$ in Europe. Growing populations, urbanization and stagnation of agricultural production poses major policy concerns in satisfying, food target goals meant to assure, at least, subsistence levels of basic food items. In the past, it would have been much easier to meet the increased food demand by expanding the area using traditional technology (extensification of agriculture). However, with the exhaustion of the supply of quality land throughout much of the region, expansion amounts to clearing of marginal land. Yields often decline as resource-constrained farmers push onto the marginal lands and over time, the removal of land cover leading to accelerated land degradation. If prudent land management practices are not followed, continued expansion of land poses a serious threat to the environment, as well as to food security goals [10]. National policies in some countries have had a negative influence on sorghum utilization as food. For instance, large imports of cheap wheat and rice and policies to subsidize production of these crops in developed and 
some developing countries have had considerable negative impact on the production of sorghum [11].

FAO reported the United States of America was the top producer of sorghum in 2009, with a harvest of 9.7 million tonnes. The next four major producers of sorghum, in decreasing quantities, were India, Nigeria, Sudan and Ethiopia. The other major sorghum producing regions in the world, by harvested quantities, were Australia, Brazil, China, Burkina Faso, Argentina, Mali, Cameroon, Egypt, Niger, Tanzania, Chad, Uganda, Mozambique, Venezuela and Ghana [12].

Sorghum, in general, is a very competitive crop and does well in competition with weeds in narrow rows. Sorghum produces a chemical compound called sorgoleone, which the plant uses to combat weeds. The chemical is so effective in preventing the growth of weeds it sometime prohibits the growth of other crops harvested on the same field. To address this problem, researchers at the Agricultural Research Service found two gene sequences believed to be responsible for the enzymes that secrete the chemical compound sorogoleone [13]. The discovery less soil toxicity and potentially target gene sequences in other crops to increase their natural pesticide capabilities, as well [13].

An international effort is under way to improve sorghum farming. The International Crops Research Institute for the Semi-Arid Tropics (ICRISAT) has improved sorghum using traditional genetic improvement and integrated genetic and natural resources management practices. New varieties of sorghum from ICRISAT have now resulted in India producing 7 tons/ha [14]. Some 194 improved cultivars are now planted worldwide. In India, increases in sorghum productivity resulting from improved cultivars have freed up six million hectares of land, enabling farmers to diversify into high-income cash crops and boost their livelihoods [15]. This research was conducted in order to compare the performance of the hybrids varieties with the local varieties that the farmers were used to in the area so as to advise the local farmers to use the varieties with the highest performance.

\section{Materials and Methods}

Five sorghum hybrids and four local varieties were collected from Institute for Agricultural Research, Ahmadu Bello University Zaria, Kaduna state (Samsorg 40, 45 and 46, CSR01 and CSR02) and Turare villege Dutsin-Ma, Katsina sate (Yargidanwudu, Zago, Jandawa and Maibakicona), respectively. The farm area used is $571.8 \mathrm{~m}^{2}$. It is located on latitude $12^{\circ} 19^{\prime} 17.5^{\prime \prime} \mathrm{N}$ and longitude $7^{\circ} 27^{\prime} 28.8^{\prime \prime}$ E. Random table number was used to allocate the sorghum varieties to plots.

\subsection{Experimental Design}

Planting for evaluation of the genotypes was done using randomized complete block design (RCBD) in three replications. Seeds are allocated to plot using random table number.

\subsection{Pre-planting Operations}

Ridges were prepared using tractor. There were three replications with each replication consisting of nine plots and each plot consists of four ridges of $5 \mathrm{~m}$ length. Inter row spacing was $75 \mathrm{~cm}$ while intra row spacing was $30 \mathrm{~cm}$. Few seeds were sown per hill and the plants were thinned down to two plants per stand two weeks after sowing.

\subsection{Cultural Practices}

$\mathrm{N}: \mathrm{P}: \mathrm{K}(15: 15: 15)$ compound fertilizer was applied to the plants two weeks after sowing and urea was used as top dress at six weeks after sowing .

Weeding of the farm was done $21 \mathrm{~d}$ after sowing and pesticide was applied to the plants to treat against stemborer.

\subsection{Data Collection and Analysis}

Duncan's multiple range test (DMRT) was used to 
rank the data using SAS 9.13.

Data collected include:

(1) Day to $50 \%$ flowering $(\mathrm{D} 50 \% \mathrm{~F})$ : the number of days for $50 \%$ of the plants per plot to flower.

(2) Plant height (PHT): the distance between the ground level to the apex of the panicles measured in centimetres at maturity being averaged from three randomly chosen plants.

(3) Panicle length (PNLE): distance between the bases of the panicle to the tip in centimetres being averaged from three randomly chosen panicles.

(4) Panicle circumference (PNCIR): diameter of the panicle girth being averaged from three randomly chosen panicles.

(5) Panicles per plot (PP): total number panicle per plot counted at harvest

(6) Panicle weight (PWP): panicle weight in kilograms per plot before threshing.

(7) Grain weight per plot (GWP): grain weight in kilograms per plot after threshing.

(8) Plant vigor (VGR): this was scored by examining growth of the seedings.

(9) Number of established seedlings two weeks after sowing (NHE).

(10) Panicle appreciation (PNLAP): this is scored by examining the seeds set on the panicle $(1=$ excellent, 2 = very good, $3=$ good, $4=$ poor, $5=$ very poor).

(11) Weight of 1,000 seeds (THR, g).

(12) Grain yield per hectare (GY): this was obtained using the formula below:

$$
\mathrm{GY}=\frac{\text { Grain weight }}{\text { Plot area }} \times 10000
$$

\section{Results and Discussion}

Samsorg 45 and Samsorg 46 were new released by ICRISAT in 2016 and were nutritionally high sorghum varieties, with three times high iron content [16], it was envisage to be a boost for farmers as well as the malnourished populations, especially children in Nigeria. Both varieties have yields that are double the local varieties are also shorter duration allowing farmers to adapt better to climate change (Table 1).

Samsorg 45, 46, 40, CSR01 and CSR02 maintained their earliness in the study location. Samsorg 40 and Samsorg 45 were far earlier with 54 $\mathrm{d}$ to flowering, then Samsorg 46 with $66 \mathrm{~d}$ to flowering against the $90 \mathrm{~d}$ on average of other varieties. This is in line with work of Showkat et al. [16]. These hybrids exhibit extra earliness and heavier panicle and grain weight compared to the local varieties used in this research. This was in line with work of Showkat et al. [16]. CSR01 and CSR02 were affected by drought this make their yields to be very low. In fact lower than that of the local varieties. There were no signs of striga even though the area was striga infested zone. This shows that the varieties were resistant to striga. This development is expected because most of the varieties used were improved varieties except for the local varieties that the status were not ascertained since they were gotten from the local community.

\section{Conclusions}

It was evidence from this work that Samsorg 45 and Samsorg 46 performed very well in Turare village than the local varieties the villagers were used to. In fact all the five hybrids brought from IAR Zaria performed far better than the local varieties produced in the Turare village. Samsorg 45 and Samsorg 46 were advantageous to the farmers not because of their early maturity but also high yielding and high nutritive contents. These attributes will enhance the market demand of these varieties and will in no doubt be relatively translated to higher income of the farmers. It is noteworthy to say that there is the possibility of planting Samsorg 40 and Samsorg 45 twice by the farmers. This will increase the farmers' turn over and improve their means of livelihood. These can be supply to the farmer to boost their sorghum production and as a mean of food availability and security. 
Table 1 Mean performance of twelve traits in sorghum.

\begin{tabular}{|c|c|c|c|c|c|c|c|c|c|c|c|c|c|}
\hline $\mathrm{N}$ & Variety & NHE & VGR & $\mathrm{D} 50 \% \mathrm{~F}$ & $\begin{array}{l}\text { PHT } \\
(\mathrm{cm})\end{array}$ & $\begin{array}{l}\text { PNLE } \\
(\mathrm{cm})\end{array}$ & NPH & PNCIR & PNLAP & $\begin{array}{l}\text { PWP } \\
(\mathrm{kg})\end{array}$ & $\begin{array}{l}\text { GWP } \\
(\mathrm{kg})\end{array}$ & $\begin{array}{l}\text { THR } \\
(\mathrm{g})\end{array}$ & $\begin{array}{l}\mathrm{GY} \\
(\mathrm{kg})\end{array}$ \\
\hline 1 & YARGIDANWUDU & $33.33 \mathrm{ab}$ & $3.67 \mathrm{ab}$ & $85.00 \mathrm{~b}$ & $294.67 \mathrm{a}$ & $22.67 \mathrm{ab}$ & $93.00 \mathrm{~b}$ & $8.11 \mathrm{ab}$ & $1.00 \mathrm{~b}$ & $1.40 \mathrm{bc}$ & $1.04 \mathrm{bc}$ & $22.00 \mathrm{a}$ & $695.6 b c$ \\
\hline 2 & Samsorg 45 & $37.00 \mathrm{ab}$ & $4.00 \mathrm{ab}$ & $54.00 \mathrm{~g}$ & $232.22 b c$ & $15.78 \mathrm{~b}$ & $93.00 \mathrm{~b}$ & $7.89 \mathrm{~b}$ & $1.33 \mathrm{ab}$ & $3.57 \mathrm{a}$ & $2.80 \mathrm{a}$ & $28.67 \mathrm{a}$ & $1868.9 \mathrm{a}$ \\
\hline 3 & Samsorg 46 & $44.33 \mathrm{a}$ & $4.33 \mathrm{a}$ & $66.00 \mathrm{f}$ & $218.00 \mathrm{c}$ & $18.67 \mathrm{~b}$ & $145.67 \mathrm{a}$ & $9.89 \mathrm{ab}$ & $1.33 \mathrm{ab}$ & $3.33 \mathrm{a}$ & $2.24 \mathrm{a}$ & $23.33 \mathrm{a}$ & $1495.6 \mathrm{a}$ \\
\hline 4 & Samsorg 40 & $37.667 \mathrm{ab}$ & $4.00 \mathrm{ab}$ & $54.00 \mathrm{~g}$ & $195.11 \mathrm{c}$ & $20.33 b$ & $96.67 b$ & $8.67 \mathrm{ab}$ & $1.33 \mathrm{ab}$ & $2.47 \mathrm{a}$ & $1.37 \mathrm{~b}$ & $23.33 \mathrm{a}$ & $915.6 \mathrm{~b}$ \\
\hline 5 & MAIBAKINKONA & $27.33 b$ & $3.33 \mathrm{~b}$ & $80.00 \mathrm{c}$ & $275.33 \mathrm{ab}$ & $16.78 \mathrm{~b}$ & $89.33 b$ & $11.67 \mathrm{a}$ & $1.67 \mathrm{ab}$ & $1.62 \mathrm{bc}$ & $1.36 \mathrm{~b}$ & $22.00 \mathrm{a}$ & $906.7 \mathrm{~b}$ \\
\hline 6 & JANDAWA & $39.33 \mathrm{ab}$ & $3.67 \mathrm{ab}$ & $80.00 \mathrm{c}$ & $289.00 \mathrm{a}$ & $35.67 \mathrm{a}$ & $111.33 \mathrm{ab}$ & $6.89 \mathrm{~b}$ & $2.00 \mathrm{a}$ & $1.67 \mathrm{bc}$ & $0.77 \mathrm{bcd}$ & $24.67 \mathrm{a}$ & $511.1 \mathrm{bcd}$ \\
\hline 7 & ZAGO & $33.33 \mathrm{ab}$ & $3.67 \mathrm{ab}$ & $99.00 \mathrm{a}$ & $307.56 a$ & $26.78 \mathrm{ab}$ & $101.33 \mathrm{ab}$ & $6.78 \mathrm{~b}$ & $2.00 \mathrm{a}$ & $1.67 \mathrm{bc}$ & $0.68 \mathrm{~d}$ & $20.667 a$ & $455.6 \mathrm{~cd}$ \\
\hline 8 & CSR01 & $37.33 \mathrm{ab}$ & $3.67 \mathrm{ab}$ & $74.00 \mathrm{~d}$ & $238.89 b c$ & $16.11 \mathrm{~b}$ & $99.33 b$ & $9.44 \mathrm{ab}$ & $2.00 \mathrm{a}$ & $1.13 \mathrm{c}$ & $0.26 \mathrm{~d}$ & $22.00 \mathrm{a}$ & $173.3 d$ \\
\hline 9 & CSR02 & $40.67 \mathrm{ab}$ & $4.33 \mathrm{a}$ & $73.00 \mathrm{e}$ & $291.00 \mathrm{a}$ & $29.56 \mathrm{ab}$ & $78.00 \mathrm{~b}$ & $8.78 \mathrm{ab}$ & $2.00 \mathrm{a}$ & $0.85 \mathrm{c}$ & $0.15 \mathrm{~d}$ & $23.00 \mathrm{a}$ & $102.2 \mathrm{~d}$ \\
\hline & $\mathrm{SE} \pm$ & 4.66 & 0.23 & 0.00 & 14.05 & 4.34 & 14.22 & 1.09 & 0.22 & 0.37 & 0.20 & 2.66 & 131.49 \\
\hline
\end{tabular}

The means followed by the same letter(s) are not significantly different using DMRT at $5 \%$ level of significance.

$\mathrm{NHE}=$ number of hills established; VGR = seedling vigor; $\mathrm{D} 50 \% \mathrm{~F}=$ day to $50 \%$ flowering; $\mathrm{PHT}=$ plant height; $\mathrm{PNLE}=$ panicle length; $\mathrm{NPH}=$ number of panicles at harvest; PNCIR = panicle circumference; PNLAP = panicle appreciation; PWP = panicle weight in kilogram; THR = weight of 1,000 seeds; GWP = grain weight per plot measured in kilogram; GY = grain yield per hectare measured in kilogram. 


\section{A Comparism of Sorghum Yield between Local Varieties in Turare, Katsina State and Sorghum Hybrids from IAR Zaria, Kaduna State}

\section{References}

[1] Prasad, V. V. P., and Scott, A. S. 2010. "Growth and Production of Sorghum and Millet." In Soil, Plant Growth and Crop Production, Vol. 2, 36.

[2] Food and Agriculture Organization of the United Nations. 1995. Sorghum and Millets in Human Nutrition. FAO Food and Nutrition Series, No. 27, FAO, Rome, Italy.

[3] Vijaya, S., Chuc, T. N., Erik, V. O., David, J., Scott, C., Greg, M., Zheng, B. Y., and Graeme, H. 2015. "Heat Stress Effect on Grain Sorghum Productivity-Biology and Modeling." In Proceedings of the 17th ASA Conference: Building Productive, Diverse and Sustainable Landscapes, September 20-24, 2015, Hobart, Australia.

[4] Prasead, P. V. V., Pisipati, S. R., Mutava, R. N., and Tunistra. 2008. "Sensitivity of Grain Sorghum to High Temperature Stress during Reproductive Development." Crop Science 48: 1911-7.

[5] Nguyen, C. T., Singh, V., van Oosterom, E. J., Chapman, S. C., Jordan, D. R., and Hammer, G. L. 2013. "Genetic Variability in High Temperature Effects on Seed-Set in Sorghum." Functional Plant Biology 40 (5): 439-48.

[6] Singh, V., Nguyam, C. T., van Oosterom, E. J., Chapman, S. C., Jorrdan, D. R., and Hammer, G. L. 2015. "Sorghum Genotypes Differ in High Temperature Responses for Seed Set." Field Crop Research 171: 32-40.

[7] Angarawai, I. I., Ajeigbe, H. A., Yeye, M., and Aba, D. A. 2017. "Characterization of Landrace Sorghum Lines for Utilization in Hybrid Parent Development." In Proceedings of the Genetic Society of Nigeria (GSN) 41st Annual Conference, 437-41.

[8] Popescu, A., and Condei, R. 2014. "Some Considerations on the Prospects of Sorghum Crop." Scientific Papers Series Management, Economic Engineering in Agriculture and Rural Development 14 (3): 295-304.

[9] Taylor, J. R. N. 2003. "Overview: Importance of Sorghum in Africa." In Workshop on the Proteins of Sorghum and Millets: Enhamcing Nutritional and Functional Properties for Africa, Vol. 2, 1-21.
www.afripro.org.uk/papers/Paper01Taylor.pdf.

[10] Scherr, S., and Yadav, S. 2001. "Land Degradation in the Developing World: Issues and Policy Options for 2020." In The Unfinished Agenda: Perspectives on Overcoming Hunger, Poverty, and Environmental Degradation, IFPRI, Washington, D.C.

[11] FAO/WFP. 2000. FAO/WFP Crop and Food Supply Assessment Mission to Sudan. Special report, FAO Global Information and Early Warning System on Food and Agriculture World Food Programme, FAO/WFP, Rome.

[12] Hussein, M., Younes, A., Ali, M., and Abd El-azim, A. 2016. "Effect of Sorghum Replacement and Probiotic on Growth Performance and Feed Utilization of the Nile Tilapia (Oreochromis niloticus).” Egyptian Journal of Aquatic Biology and Fisheries 20 (2): 113-21.

[13] O’Brien, D. 2010. “Tapping into Sorghum's Weed Fighting Capabilities to Give Growers More Options." United States Department of Agriculture, Agricultural Research Service. Accessed June 15, 2018. https://www.ars.usda.gov/news-events/news/research-ne ws/2010/tapping-into-sorghums-weed-fighting-capabilitie s-to-give-growers-more-options/.

[14] Srinivas, R. 2016. "India Beats China in Sorghum Production." The Hindu. Accessed June 15, 2018. http://www.thehindu.com/todays-paper/tp-national/tp-and hrapradesh/india-beats-china-in-sorghum-production/artic le5791021.ece.

[15] Trading Economics. 2011. "Nigeria-Sorghum Yield (kg per hectare)." Trading Economics. Accessed June 15, 2018. https://radingeconomics.com/nigeria/sorghum -yield-kg-per-hectare-wb-data.html.

[16] Showkat, R., Tinku, R., and Hakeem, A. 2016. "New Sorghum Varieties Released in Nigeria with Higher Iron, Yields and Drought Resilience." International Crops Research Institute for the Semi-arid Tropics. Accessed June $\quad 15$, 2018. http://www.icrisat.org/new-sorghum-varieties-will-fightmalnutrition-and-climate-change-in-sudan-and-sahel-regi on-of-nigeria/. 